\title{
Chaos or Breakthrough - Artistic Analysis of Cannes Award-winning Films of Recent Years
}

\author{
Haoying Liu ${ }^{1, \dagger}$ Jiayi Shi ${ }^{1, \dagger}$ Yuxin Xue ${ }^{1, *}, \dagger$ \\ ${ }^{1}$ Dulwich international high school Suzhou, Suzhou, China \\ ${ }^{*}$ Corresponding author. Email: evelyn.xue22@stu.dulwich.org \\ These authors contributed equally.
}

\begin{abstract}
Cannes has redefined art house cinema in recent years. We find that the artistic tilt of films in recent years has been broken. There seems to be a contradiction between these films and previous films. Is there any rule in these contradictions? Is that really a departure from artistry? Is that a departure from what we said before about artistry? In this part, we will select award-winning films in recent years and analyze the laws and artistry of films. Due to the limited space, we gave up the analysis of the sense of form but focused on the theme to show the changes in art.
\end{abstract}

Keywords: Cannas films, Dissemination, Social Media

\section{INTRODUCTION}

In the field of art, many things are dialectically unified. For example, majority or minority, artistic films or commercial films. In today's society, media is a significant part of society, and everything has become diversified. In this context, whether some traditional things can be analyzed from a more dialectical perspective, such as the artistry in movies. Cannes films, which are biased towards art films, also face such problems. Compared with the single elements before, they become more diversified. In this social situation, this paper will analyze whether artistry in Cannes films is a constant concept and whether it is in a dilemma or a breakthrough.

\section{THE HISTORY OF FILM DEVELOP- MENT AND THE CHANGE OF CANNES FILM STYLE}

In the field of art, many things are dialectically unified. For example, majority or minority, artistic films or commercial films. In today's society, media is a significant part of society. Everything has become diversified. In this context, whether some traditional things can be analyzed from a more dialectical perspective, such as the artistry in movies. Cannes films, which are biased towards art films, also face such problems. Compared with the single elements before, they become more diversified. In this social situation, this paper will analyze whether artistry in Cannes films is a constant concept and whether it is in a dilemma or a breakthrough.

\subsection{The history of films}

The film, is a continuous image developed by the combination of mobile photography and slide projection. It is a visual art, and is used to share ideas and experience the film's atmosphere. The film is a cultural product created in Europe. People had influenced the world by showing their culture through films. The film is considered a significant art form and a source of popular entertainment.

In history, there were three film movements, which promoted the development of film art. The first film movement was the European avant-garde film movement centered in France. People began to pay attention to the depth of art. At this time, the film is mainly an art film. The second film movement was the Italian neorealist film movement. After the Second World War, the European economy and culture received great damage and impact. The Italian director turned the camera to the common people. Thus came Italian neorealism and an aesthetic theory of new reality. The third film movement was the French New Wave film movement. It was still centered in France. Social and political confusion was the main cause of this movement, which changed the course of the world. It emphasizes the atmosphere of life, the use of real shots, advocated improvisation, and varied shooting techniques [1].

\subsection{The artistry in films}


In movies, artistry is an indispensable factor. To some extent, artistry is the part that is linked to the hidden desire and divine natures of people and presents the aesthetic part of things. Artistry is produced for individuals, emphasizing the value and significance of people. It also emphasizes the combination of human nature and divinity in people and presenting the performance in individuals. And through the specific art form, it will reproduce the spirit [2]. Artistry can be found from different angles. In a film, the director's use of color, light and shadow and composition can show the film's artistry. The film reflects life through the plot, the expression of feeling is also the embodiment of artistic quality. With the development of the economy, the commercial proportion of movies is becoming heavier and heavier in these several years. The film industry gradually became a mature industry and became a commodity in the capitalists' minds. Commercial films pursue the market value of box office and its derivatives and aim at consumer recognition [3].

\subsection{Changing characteristics of Cannes films}

If you want to explore artistic movies, you can't say without Cannes films. The origin of films is in Europe, and so is the origin of the artistry of films. Due to historical factors and cultural inheritance, Cannes Film Festival enjoys a great reputation among many international film festivals. The feature of its award-winning works is that compared with other international film festivals, Cannes films are rich in artistry and pay more attention to the artistic techniques, thoughts and feelings in films, which is honored as the temple of art films. Cannes Film Festival is one of the most influential and top international film festivals in the world. An art film is also one of the most famous features of the Cannes Film Festival. Cannes films have many kinds of artistic displays.

Due to the changing times, Cannes Film Festival in recent years has undergone some changes due to changing era despite its heavy artistic weight. First, the artistic form changed. In the past, in contrast to Hollywood films, it did not have smooth editing and used surrealist style, including film noir (A particular style of film often concerned with moral decay). The audience can't appreciate what the movie is trying to say. But we can see the different characteristics of human nature, and this sense of form has a huge impact on the audience. However, in recent years, Cannes films have had smooth editing and a greater emphasis on the use of color, light and shadow. Also, Cannes films have been more inclined to feature films (stories based on events that often exist in real life but are often unnoticed by most people). Compared with seeing the different characteristics of human nature, feature films focus on criticizing social phenomena and ethos. Although the audience can understand the plot, the irony behind the story is worth reflecting on. Secondly, the artistic content changed. Previously, Cannes films focused on subcultures in society. These groups are very different from us and appear to be social misfits. Nor does it have much to do with our universal values. But it can touch people's deep emotions. Now, Cannes films tend to be those that discuss social issues and those that have a depth of art. Film selection is more concerned about reflecting life, the performance of the thoughts and feelings for the director by the movie to explore social issues, and criticizing something to show the film's artistry. Thirdly, Cannes films achieved greater success at the box office. Historically, Cannes films have not been accepted by the audience and have not achieved very high box office achievements. But in recent years, Cannes films have achieved great success at the box office. Take the movies which won Palme d 'Or, for example, Dancer in the Dark (2000), which had 45.6 billion box office. "The Tree of Life" grossed 61.7 billion in 2011. But 2018's "Shoplifters" and 2019's "Parasite" grew to 76.9 billion and 264.4 billion. People's acceptance of art films is increasing not only because commercial elements have been added to the films in Cannes, which has increased the popularity of the films, but also because audiences' thoughts are progressing. The pursuit of artistry is also improving.

The former Cannes films and the current Cannes films seem to present a certain state of contradiction in terms of artistry. This paper is to analyze this contradiction. In this paper, the Cannes films in recent years have been defined from 2000. The following will take this as the timeline and extract the corresponding text for analysis.

\section{USING SPECIFIC EXAMPLES TO ANA- LYZE THE ARTISTIC CHANGES OF CANNES FILMS}

\subsection{Take individuals as examples to capture the changes of The Times}

Firstly, It resonates with a smaller group than it used to. In recent years, award-winning films have emphasized the community among individuals, which can strike a chord with the masses. Homosexuality has become a hot topic in recent years. In 2013, the film La Vie d'Adèle directed by Spanish director Abdellatif Kechiche was also awarded top honors with a striking theme: love and youth no need for gender, only parting and standing out from the crowd. The love between the same sex is no different from the opposite sex. It starts with the heart and ends with a simple goodbye. The film contains many artistic elements such as close-ups, slapping her open mouth to sleep, eating pasta with ketchup all over her mouth, snot running down her face when she cries. These all bring the viewer closer to the main character in the film. What's more, one movie called La Vie d'Adèle also represents changes in ages in the main character Blake's view. In the first scene of the movie, Blake can't understand modern technology, which cost him a lot of time. 
Time is changing, and technology can be convenient for us in many ways, such as communication or work. However, not everyone can adapt to the development, like our main character, his disease is getting worse, and he needs to find a suitable job. If he successfully adapts to the changes, it would be another story to tell.

\subsection{Individual anxiety under modern conflict}

Secondly, compared with previous films, recent films have added life factors based on expressing the inner world of the protagonists. Jane Campion's film-The Piano, by contrast, strikes a balance between art and commerce. A sharp and piercing question is raised in this film: whether women have independent spiritual personalities. When a woman is loveless and unable to communicate normally, the piano becomes her only consolation. When Ada gazed at the piano left on the beach in the storm, the longing in her eyes showed a kind of solitude and stubbornness, which was not loving, but a type of dependence that was almost paranoid. Perhaps the contradiction of a woman is that what she desires in her heart is often what she tries to avoid being detected in her appearance, so she must express it gently through the secret means of playing the piano, making the process and effect of expression seem so long and slow. Even if the movie's storyline is a little less than satisfying, the color and background music complement each other, giving the audience visual enjoyment. Next, The film Parasite best indicates the class contradiction between the wealthy and the poor. No matter what time through the history you are, there's always boundaries such as human rights discrimination for the poor. It is very difficult for them to climb up to the higher class [4]. However, the poor family in the film parasite successfully experienced how the rich lives by tricks. During their stay in the rich's house, all the family members were anxious and worrying about being found to be fake house workers. In addition, they were afraid of losing such wonderful life and go back to be poor. The inner human emotion performed very vividly in the film. With the decoration of the plot, it precisely shows that under this hierarchy, people from different class is never about to be in the same conversation. The movie dancer in the dark shows a mother working hard to save money for her son's eyes surgery. She has a congenital eyes problem and has already passed to her son's genes. In reality, she couldn't tell her son how hard her work was and how bad are her eyes. The director vividly uses the screen and clearly telling us how love can be powerful but also soundless. The accident still happened after the mother successfully saved up all the money, the anxiety then updated, the real problem in the world can crush a person or make him even stronger. Still, cost exists, such action touched hundreds of viewers to be strong.

\subsection{Epic works show the ups and downs of hu- manity}

Finally, the themes of epics have become more general and diverse. War as the first choice for commercial films, sometimes as a literary film script, can also reap box office and awards. A World War II film about jews and Nazis--the Pianist, A highly rated film directed by Rajmund Roman Liebling that won the Palme d 'Or at Cannes in 2002. Unlike commercial movies full of special effects, this film has few special effects, and there are almost no explosions or bombing scenes. The complete storyline and clear logic make people cannot help to think about the evil of war. Since this film is a retelling of a real story, it's more brutal and less dramatic than making people feel calm and frighten. Even today, countless eyes are waiting for peace in malicious war-torn places. Similarly, The European film with the theme of war and peace, The Wind Blows the Wheat, also shows the splendor of war to people in the form of art film. The film, set against British rule in Northern Ireland in 1920, was reviewed by the British press as a sketch of the Irish Republican Army and a veiled condemnation of the British totalitarian regime. And the film itself, with the help of two brothers, with violence to resist violence, and ultimately because of the violence of the ownership of the issue and turned into a tragedy. The film is still famous for its story, even without the astonishing, extraordinary spectacle, the proper background music mixed in with gunfire and wailing to immerse the audience in history. People don't usually have a choice in war. At the end of the film, Damian, who is about to be executed by his brother Teddy, writes in his suicide note: "I tried not to get involved in this war, I got involved, and now I want to get out, but I can't." Such was his fate as an Irishman.

What has traditionally been defined as art has not been erased but expanded the space of art. This may be a good match for commercial films. And that may be the reason for the commercial success. These commercial perspectives have attracted more attention to the film.

\section{SPECULATION ABOUT THE FUTURE OF ART FILMS}

In the current social trend, the value of art films will not decline but will increase. Most of today's films use both artistic and commercial (mass) film products to infect the audience, win the market and realize lessons [5]. The current situation of the Cannes Film Festival, which specializes in creating literary and artistic films, can be seen. Art film has gained a high reputation from its glory to its downfall, which is a breakthrough. For example, Cannes Film Festival, as one of the most influential international film festivals in the world, has been expounding the artistry of films. Its award-winning films were unpopular in the past, but now Cannes award-winning films have also made great commercial achievements, with countless good reputations and box office. Is Cannes' commercial success accidental. Cannes' awardwinning films, whether the pianist in 2002 or the parasite, 
which set off many splashes last year, also have high artistry and expression of human nature. Now they also smooth and generalize some film plots so that the film itself is no longer an individual but a group. Not in the silent corner, still struggling, but reborn [6].

\subsection{The predicament and breakthrough of liter- ary film}

Is this still a dilemma? Does this mean that the Cannes Film Festival is no longer art? The answer is no, movies can break through, and literary and artistic films can break through. They break through the limitations, only reflect the sense of self and individuality, break through such shackles, and find a balance between artistic expression, personal feelings and audience identity. Compared with the current art commercial compatible film model, the previous films emphasized a sense of self, personality, and form better. Still, even though they are very artistic, the box office is very bad. Although artistry, the audience can see human nature and all kinds of thought-provoking human corners through the film, there is no good achievement at the box office. Even if the audience of literary and artistic films has never been the public. Today's Cannes award-winning films are still artistic. They still retain the personality and form of art itself, but they succeed by adding some new elements. This is also a common point between Cannes films before and now. They are interpreting human nature and exposing various corners of human nature in life in an artistic form. These art films have always been like a pluralistic mirror, reflecting the real spiritual world of today's human beings. However, commercial films have been added, and their plot and casting also take into account the public's perception, such as whether people can understand the inside of the film, people feel bored when watching the film, and so on. Through the Cannes awardwinning film parasite mentioned above, the box office of the film parasite exceeded 2.2 billion. At the same time, the audience also described the film parasite as full of metaphorical features of Jung's psychological theory from the title to the plot, projecting many profound problems. The film does not deliberately exaggerate the sad atmosphere, but the story itself is a tragedy. In addition, the famous "the pianist" has become an artistic and commercial cooperative film, which has won a high reputation and box office [7].

\subsection{The reasons behind the commerciality of art films}

All these mean that films can be commercial and artistic, and the reasons behind this are also worth studying. First of all, the public's aesthetics are gradually improving. People's aesthetic needs are becoming more and more diversified and becoming more and more standardized. This is the result of economic and cultural develop- ment and the conscious requirement and historical embodiment of people's desire to promote their essential strength and make their body and mind develop comprehensively and freely after their scientific and cultural quality is improved. Many people say that public aesthetics determine the current situation and future of Chinese films. So now people are not stuck in some conventional plots. People pursue high-quality and high-content films. So this is also the reason why artistry can succeed now. Secondly, the concept of filmmakers and the public's perspective also prove that films can be commercial and artistic. From the public point of view, commercial literary and artistic films are more famous, so they are more willing to understand. To make it more acceptable to the public, producers usually smooth and generalize the content so that as many people as possible can understand the connotation. For filmmakers, the success of their combination of literary and commercial films usually depends on their attention and pursuit of the market. From the plight of literary and artistic films, the modification of the producers' narrative techniques and the changes in cultural feelings, it is proved that literary and commercial can occur at the same time. Finally, the general environment of today's era is also changing. Today's environment is very mature and relatively peaceful in various professional fields. All kinds of commercialization and profitability have also become a trend. In a relatively impetuous society, people can rarely pursue literary and artistic films with a strong sense of self [8]. The film with artistic beauty and profound meaning is relatively easy to understand and is a film with great advantages to making a profit.

\subsection{The future of art film}

Even though the film was purely artistic at first, and now it has entered the public view together with commerciality, we still can't forget the appearance of the film itself. The root of art is human nature. Human nature has always been there, so artistry will not be erased. With the development of the times, artistry has gradually changed in a direction recognized by the public. Let more people understand the secret of human nature to be interpreted by the director [9]. Cannes has set a good example in this field. The relative development of Chinese literary and artistic films is still relatively slow, and many excellent literary and artistic films can not get more platforms to display. Now, Chinese literary and artistic films will make Cannes a micro target. In the Cannes Film Festival in recent years, Chinese films have also won many honors. This makes literary and artistic films break through from chaos to a bright future.

\section{CONCLUSION}


From the past to the present, the evaluation criteria of Cannes films have changed, the concept of artistry is no longer the same as before, and commercial elements have been integrated into Cannes films, creating a direction favored by the public. From this, I come to the conclusion that art and commerce can complement each other, which is the healthy development mode of film - take the essence and discard the dregs. Although the artistic tendency of films has changed in recent years, there is no contradiction between these films and previous films in terms of art, but the expression techniques have changed due to the different times.

\section{REFERENCES}

[1] Wang Lili. (2011). An analysis of the popularity and niche of art films. Young reporter (08), 49-50. doi:10.15997/j.cnki.qnjz.2011.08.002.

[2] Li Haixia (2020-07-22). On the development of art films since the new century. China film news, 008 .

[3] Xiao Qi (2017). Research on the marketing strategy of literary and artistic films in the context of commercialization (Master's thesis, Qufu Normal University) https://kns.cnki.net/KCMS/detail/detail.aspx?dbname=CMFD201801\&filename $=1017223795 . \mathrm{nh}$

[4] He Yanlin. (2021). Well deserved -- an analysis of the reasons why parasite won the first prize in Cannes. Drama House (19), 144-145. Doi: CNKI: Sun: xjzt. 0.2021-19-069

[5] Zhu mengqiu. (2019). Effective development path of domestic literary and artistic films under supply side reform. Western radio and television (09), 127. Doi: CNKI: Sun: xbgs. 0.2019-09-074

[6] Xu Xiuchun. (2021). Glory and loss: on the "unconscious gender imbalance" of Cannes Film Festival. Audiovisual (08), 25-26. Doi: 10.19395/j.cnki.1674-246x. 2021.08.010

[7] Zhong Zhaoyang. (2020). Aesthetic analysis of current domestic documentary style art films (Master's thesis, Shandong Institute of Art) https://kns.cnki.net/KCMS/detail/detail.aspx?dbname=CMFD202002\&amp;filename $=1020630524 . \mathrm{nh}$

[8] Now (2021-08-04). Novel Coronavirus Health Pass is wreaking havoc on the French summer box office. China Film News,014.

[9] Zhang Xin. (2021). Analyzing the poetry of film art from the perspective of audio-visual language. Media Forum (15), 109-110. Doi: CNKI: Sun: CMLT. 0.2021-15-054. 